\title{
The Formation and Behaviour of Vacuoles (Vesicles) during Oosphere Development and Zoospore Germination in Saprolegnia
}

\author{
By J. L. GAY, A. D. GREENWOOD AND I. B. HEATH* \\ Department of Botany, Imperial College of Science and Technology, London S.W.7
}

\author{
(Accepted for publication 22 December 1970)
}

\begin{abstract}
SUMMARY
Fine structure studies have shown that in oosphere development the protoplast of the oogonium of Saprolegnia furcata is cleaved by the formation of large vesicles which extend from the centre to join the plasmalemma. The origin and behaviour of the central vesicles is indicated by the presence in them of special granules which are identical with those in smaller cytoplasmic vesicles and in the space formed in the oogonium at cleavage. The cytoplasmic vesicles also contain dense (osmiophilic) bodies, mostly about $0.3 \mu \mathrm{m}$. in diameter, and in some fixations show proliferation of membranes. The contents of the vesicles often show lamellation as do those in vesicles in zoosporangia of $S$. ferax, where cytoplasmic cleavage occurs in the same way. The appearance of this material in sporangia coincides with an increase in the quantity of phosphatidyl choline.

The vacuoles in germinating zoospores of Saprolegnia ferax are also produced by fusion of dense-body vesicles.

The presence of vesicles of the dense-body type in many Oomycetes and other micro-organisms is recorded and their functions are discussed.
\end{abstract}

\section{INTRODUCTION}

The spores of Phycomycetous fungi, though diverse in final form and function, commonly originate by the division of the cytoplasm in a large multinucleate cell. It has long been known that in species of Saprolegnia the cytoplasm of the zoosporangium is segregated first into uninucleate lobes at the periphery of the cell by the formation of radial depressions which extend gradually closer to the wall until finally, and more or less simultaneously, the lobes become completely detached and converted into spores. Investigation of the fine structure in Saprolegnia ferax (Gay \& Greenwood, I966) has shown that the lobes are separated by the enlargement, contact and fusion of internal cytoplasmic vesicles. Electron micrographs of sections of sporangia fixed at late stages of cleavage (Pl. I, fig. 3) showed that the ends of all the furrows between adjacent lobes of the cytoplasm were almost in contact with the plasmalemma, which up to this stage appeared not to be involved. Immediately after cleavage each lobe had been converted into a separate zoospore limited by a single plasma membrane. There then remained no large vesicles in the zoospores, no vestige of plasmalemma membrane lining the sporangium wall (Pl. I, fig. I), nor any detached vesicles or fragments of cytoplasm in the continuous space between the spores. It was concluded that the spores were cut out by localized fusion and reconstitution of membranes in

\footnotetext{
* Present address: Department of Botany, University of Georgia, Athens, Georgia 3060r, U.S.A.
} 
the tracts where the furrows about the plasmalemma and that the internally derived membrane of the furrows and the plasmalemma became wholly incorporated into the limiting membranes of the spores.

The above interpretation of the static fine structure was supported by observations on the behaviour of sporangia in life. During the terminal stages of sporogenesis, following vacuolation and delimitation of the lobes in the peripheral cytoplasm, the sporangium as a whole underwent a sudden decrease in volume (Pl. I, fig. 2a, b) and shortly afterwards the spores could be seen as separate bodies (Pl. I, fig. $2 c$ ). In early descriptions of these critical events, Rothert (1888) and also Hartog (I888) noted that immediately a sporangium shrinks it becomes attractive to bacteria. These observations indicate that physiologically active solutes are released from a sporangium when it decreases in volume, which can be accounted for by a sudden increase in permeability following the reorganization and final breakdown of membranous barriers between the vacuole and the wall of the sporangium, resulting in loss of turgor and expulsion of fluid previously contained in the vacuole.

It was suggested (Gay \& Greenwood, I966) that in the zoosporangium of Saprolegnia ferax the vesicles which cleaved the cytoplasm were developed from smaller vesicles which contained large, osmiophilic, electron-opaque inclusions (dense bodies).

The work described here shows that the dense-body vesicles function similarly in vacuolation during the formation of oospheres and germination of zoospores in Saprolegnia. It also indicates the possible nature of the contents of these vesicles.

\section{METHODS}

Cultures of Saprolegnia furcata Maurizia were grown from material kindly supplied by Dr M. Dick, University of Reading, on autoclaved hemp grains in water. The grains were inoculated by placing them on the surface of an agar culture at $25^{\circ}$. They were removed after $24 \mathrm{~h}$. and put separately in Petri dishes containing approximately $20 \mathrm{ml}$. sterile distilled water. Oogonia developed during incubation in the dark at room temperature (about $23^{\circ}$ ) or at $25^{\circ}$.

Sporangia of Saprolegnia ferax (Gruithuisen) Thuret and Dictyuchus sterile Coker (strain 34I c) were obtained when mycelia grown in liquid chick-pea extract were transferred to water as described by Gay \& Greenwood (1966). Alternatively the nutrient medium (glucose, ro g.; peptone, 1 g.; yeast extract, $0 . \mathrm{I}$ g.; $\mathrm{KH}_{2} \mathrm{PO}_{4}$, I $\cdot 0$ g.; $\mathrm{MgSO}_{4} \cdot 7 \mathrm{H}_{2} \mathrm{O}, 0.3 \mathrm{~g}$.; distilled water, I 1.) was used in place of chick-pea extract. The zoospores were induced to germinate by transfer to the nutrient medium.

Entire cultures were fixed by a variety of methods. Glutaraldehyde was used at room temperature for $2 \mathrm{~h}$. at concentrations of $2.5 \%(\mathrm{v} / \mathrm{v})$ or $5 \%(\mathrm{v} / \mathrm{v})$ in M IO or MI5 sodium phosphate buffer at $\mathrm{pH}_{7}$ for oogonia and zoospores respectively, followed by four Io min. periods in fresh buffer and I \% (w/v) OsO $\mathrm{O}_{4}$ in buffer for $\mathrm{I} \mathrm{h}$. Alternatively, fixation was in buffered cold I \% (w/v) $\mathrm{OsO}_{4}$ or $2 \%(\mathrm{w} / \mathrm{v}) \mathrm{KMnO}_{4}$. Ethanol was used for dehydration and after transfer through mixtures of graded concentrations of ethanol, epoxypropane and Epon the material was flat embedded in Epon. A light microscope was used to select cells at stages comparable with those observed in life, which were sectioned in a known plane with a diamond knife.

Sections were stained in $I \%(w / v)$ aqueous uranyl acetate for 20 to $30 \mathrm{~min}$. at $60^{\circ}$ and/or lead citrate (Reynolds, 1963) for 4 to $10 \mathrm{~min}$. at room temperature. Estimates 
of volume fractions were obtained from micrographs using a point lattice as described by Freere \& Weibel (1967).

Lipids were extracted and characterized according to Mangold (1965). Mycelia were grown for 3 days, washed twice with $20 \mathrm{ml}$. distilled water and disintegrated in groups of five in $10 \mathrm{ml}$. chloroform + methanol $(2+\mathrm{I}, \mathrm{v} / \mathrm{v})$ in a Potter homogenizer at $0^{\circ}$. Each extract was centrifuged and a portion $(6 \mathrm{ml}$.) was removed from the lower layer. The solvents were removed in an evacuated rotary evaporator at $34^{\circ}$ and the residue was dissolved in I ml. chloroform + methanol. Five $\mu$ l. quantities were applied to thin layers of silica gel $\mathrm{G}$ and separated into components in chloroform + methanol + water $(65+25+4$, by vol.). Alkaline bromothymol blue, rhodamine B and the ammonium molybdate, perchloric acid, stannous chloride reagent were used to detect the polar lipids. Lecithin was used as a reference.

\section{Development of the oogonium}

RESULTS

The oogonium in Saprolegnia furcata originated at the apex of a main hypha or a short lateral branch. Cytoplasm flowed into the apex, which swelled to become a spheroid 25 to $40 \mu \mathrm{m}$. in diameter. No large vacuole was observed at this stage either in living material (Pl. 2, fig. 4) or in fixed material viewed with the electron microscope (Pl. 2, fig. 5, 6). The cytoplasm appeared unchanged at the immediately following stage when a septum had formed at the oogonium neck. It included a number of small vesicles, some of which appeared empty and were situated mainly at the periphery and were thought to be concerned with wall synthesis (wall vesicles; Heath, Gay \& Greenwood, 197I). Other vesicles (Pl. 2, fig. 6) contained dense bodies similar to those in the zoosporangium of Saprolegnia ferax (Gay \& Greenwood, 1966). At a later stage (Pl. 3, fig. 7, 8) large vesicles occupied the central region of the oogonium. The nuclei were then spaced equidistantly in the peripheral cytoplasm. The centrioles ( 17 in II oogonia) observed at this and the preceding stage all lay adjacent to the nucleus and towards the periphery of the oogonium. When pairs were seen, the centrioles were orientated at $180^{\circ}$ as at nuclear interphase in the vegetative hyphae (Heath \& Greenwood, 1968, 1970).

Oogonia at this stage, fixed in osmium tetroxide and stained with uranyl acetate either alone or followed by lead citrate, showed characteristic mottled granules of irregular shape. These occurred in the central vesicles and in smaller ones which mostly contained dense bodies (Pl. 4, fig. II). Lead citrate used alone did not stain the granules. The volume fraction of the wall vesicles was small and showed little variation (Table I) while the average of the combined totals of the central and other vesicles, most of which contained dense bodies, had increased from $31 \%$ in the preceding stage to a value of $52 \%$.

In the further development of the oogonium the cytoplasm became divided to form I to Io eggs or oospheres, leaving a considerable volume of fluid-filled space in the oogonium (Pl. 5, fig. 13, I4). This space between the oospheres contained granules (Pl. 4, fig. I2) which were identical in appearance to those mentioned earlier to be present in the central vesicles and the smaller dense-body vesicles of the oogonium. Some dense-body vesicles still remained in the cytoplasm of the oospheres, but no large cytoplasmic vesicles were present. At the earliest stages examined oospheres already possessed a wall which was at first thin (Pl. 4, fig. I2; Pl. 5, fig. I3) and sub- 
sequently thick ( $\mu \mathrm{m}$.). Following cleavage of the oogonium cytoplasm, no part of the original plasmalemma remained in association with the oogonium wall (Pl. 4 , fig. I2).

\section{Germinating zoospores}

After cleavage of the sporangium, zoospores of Saprolegnia ferax and of Dictyuchus sterile contained numerous dense-body vesicles and no large vesicles or vacuoles (Gay \& Greenwood, I966; and P1. 6, fig. I7). When the zoospores of S. ferax germinated to form the first hyphae, dense-body vesicles enlarged and fused to constitute the initial vacuoles of the germlings; at this stage the vesicles present sometimes contained one, two or even several dense bodies (P1. 6, fig. I8, 19). The size of the dense bodies appeared to decrease as the vacuoles enlarged.

Table I. Volume fractions, obtained from micrographs of median sections of oogonia of Saprolegnia furcata at two stages of development, occupied by wall vesicles and all other vesicles. Most of the latter contain dense bodies

Stages $I$ and 2 are defined in the text and are represented by Pl. 2, fig. 6 and Pl. 3, fig. 7 respectively.

\begin{tabular}{|c|c|c|c|}
\hline Stage & Micrograph no. & $\begin{array}{c}\text { Wall vesicles } \\
(\%)\end{array}$ & $\begin{array}{c}\text { All other vesicles } \\
(\%)\end{array}$ \\
\hline I & 10412 & $4 \cdot 2$ & $26 \cdot 5$ \\
\hline I & 10442 & 5.9 & $32 \cdot 3$ \\
\hline I & 12127 & - & $44 \cdot 4$ \\
\hline I & Averages & $5 \cdot 0$ & $3 I \cdot I$ \\
\hline 2 & 10223 & $4 \cdot 4$ & $43 \cdot 4$ \\
\hline 2 & I 2696 & $3 \cdot I$ & $63 \cdot 7$ \\
\hline 2 & 9618 & $4 \cdot 8$ & $48 \cdot 5$ \\
\hline 2 & Averages & $4 \cdot I$ & $51 \cdot 9$ \\
\hline
\end{tabular}

\section{Composition of dense bodies}

Dense bodies seen in sporangia of Saprolegnia ferax were sometimes surrounded by parallel bands (Gay \& Greenwood, 1966). Myelin-like banding (lamellation) has been observed surrounding the dense bodies in vesicles of zoospores, oogonia and oospheres. Material fixed in glutaraldehyde and osmium tetroxide (Pl. 5, fig. I6) often had this appearance, which sometimes was seen also after osmium alone (Pl. 3, fig. I0; Pl. 4, fig. I I, I 2) but rarely after permanganate fixation (PI. 3, fig. 9). The average spacings between bands were $80 \AA$ after glutaraldehyde and osmium tetroxide fixation, $85 \AA$ after osmium tetroxide and I Io $\AA$ after potassium permanganate. It was suggested (Gay \& Greenwood, 1966) that the banded configuration indicated the presence of a polar lipid.

When Saprolegnia ferax, S. furcata and Dictyuchus sterile were grown in water culture on a substrate provided by a boiled hemp grain, both the reproductive organs and the vegetative hyphae contained dense bodies in vesicles. However, when $S$. ferax was grown in a weak aqueous extract of chick peas, dense bodies were not present in the hyphae until sporangium formation was induced by replacing the nutrient medium with water. Chromatography of extracts obtained from mycelia immediately following transfer to water showed faint spots corresponding to phosphatidyl choline. 
Extracts from mycelia which had remained in water for $4 \mathrm{~h}$. and formed many sporangia gave phosphatidyl choline spots which were conspicuous. Their intensity suggested a several-fold increase.

\section{Fixation effects on the membranes of the vesicles}

When some stages of Saprolegnia were fixed with glutaraldehyde followed by osmium tetroxide, membranous structures were produced which we consider to have been artefacts. Oogonia at the stage shown in Pl. 3, fig. 7,8 were particularly vulnerable and the central region, occupied by large vesicles following osmium fixation, has been seen after glutaraldehyde and osmium to contain an unordered mixture of broken membranes, droplets of lipid and other cytoplasmic organelles. At other phases of development glutaraldehyde affected the cytoplasm less severely; the expansion of a vesicle containing a dense body after this fixation of a zoospore of Saprolegnia ferax shown in Pl. 5, fig. I5 appeared likely to have been an artificial proliferation of membrane.

\section{DISCUSSION}

The oogonia of Saprolegnia furcata contained distinctive granules in the densebody vesicles and in the central vacuoles which formed and expanded during cleavage. Afterwards, similar granules were present in the fluid-filled continuum between the oospheres and the wall. These observations leave little doubt that cleavage started with the enlargement and coalescence of dense-body vesicles and continued by the confluence and extension of the vacuoles so formed into the planes of cleavage until the limiting membranes reached and fused with the plasmalemma, excluding the vacuolar contents from the cytoplasm in a manner analogous to reverse pinocytosis. These processes are fundamentally the same as those proposed earlier for the zoosporangium of S. ferax (Gay \& Greenwood, 1966), where there was independent evidence that cleavage vesicles developed from dense-body vesicles. The presence of one, two or more dense bodies in one vacuole in early germination stages of the zoospores of $S$. ferax showed that in this process also vacuoles originated from densebody vesicles.

The cleavage of a protoplast by the development and fusion of vesicles is a mechanism found in all other Phycomycetes where the development of internally formed spores has been investigated at the ultrastructural level (Allomyces arbusculus, Moore, 1964; Aphanomyces eutiches, Shatla, Yang \& Mitchell, 1966; Blastocladiella emersonii, Lessie \& Lovett, 1968; Gilbertella persicaria, Bracker, 1966, 1968; Phytophthora infestans, King, Colhoun \& Bulter, 1968; Phytophthora parasitica, Hohl \& Hamamoto, 1967; Rhizophlyctis rosea, Chambers \& Willoughby, 1964; Saprolegnia terrestris, Moore \& Howard, 1968.)

Special cleavage vesicles have been recognized before cleavage in only the Zygomycete Gilbertella and in Saprolegnia, but these genera show many dissimilarities and the vesicles also are quite different in their characteristics. Although vesicles similar to those of the dense-body type have been illustrated, in the other Oomycetes listed above where sporangium cleavage has been described, they have not been implicated in the cleavage process.

Dense-body vesicles have also been observed in the mature spores of Dictyuchus sterile and in Achlya bisexualis and Plasmopara viticola (J. L. Gay, unpublished results), 
and vesicles with contents that are morphologically similar have been described in several other Oomycetes (Achlya ambisexualis and $A$. imperfecta, Tontz, 1969; Phytophthora capsici, Katsura, 1970; P. erythroseptica, Chapman \& Vujičić, I965; $P$. megasperma, Ho, Zachariah \& Hickman, I968; $P$. parasitica, Reichle, 1969). Although the vesicles are not necessarily confined to reproductive stages (under some nutritional regimes, for example when grown on hemp grains, they occur in vegetative hyphae of Saprolegnia species), they clearly play an essential part in the formation of vacuoles at preferred sites in the cytoplasm at various stages in the asexual and sexual reproductive cycles of some species.

Two important functions of dense-body vesicles in Saprolegnia are (i) the production of additional membrane incorporated in the tonoplasts of the vacuoles; the ability of the vesicles to become centres of membrane formation is also indicated by the readiness with which membranes proliferated from them under the influence of glutaraldehyde; and (ii) the differential movement of fluid into the expanding vesicles. During cleavage there is little change in the volume of the containing cell but the reduction in the volume of the cytoplasm indicates that it, as distinct from its vesicles, must become dehydrated to an extent approximately equivalent to its change in volume, unless there is a corresponding loss of dry matter. Subsequently the volume of the spores in a fresh-water environment appears to be adjusted and maintained by different mechanisms. In swimming zoospores contractile vacuoles become active after cleavage (Gay \& Greenwood, 1966) and in oospores the cytoplasm is restrained by a wall, which present results show may be initiated with little or no delay after the oospheres become separately defined. The germination of encysted zoospores, unlike the preceding events of sporogenesis, results in an increase in the total volume enclosed by the plasmalemma, but this increase also depends upon an uptake of fluid by the dense-body vesicles and their enlargement, which leads to a proportionately much greater increase in volume of the vacuoles compared to the surrounding cytoplasm.

In the formation of oospheres and the formation and germination of zoospores the contained dense bodies disappear or shrink as the vesicles expand and fuse. It is therefore possible that some of the constituents of the dense bodies may become transformed into components of the growing membranes or that they may be concerned directly in the mechanism by which water is taken into the vesicles, for example by becoming hydrated or broken down into smaller molecules effective in osmotic or metabolic modes of water transfer. In this connexion the resemblance of the banded zones of dense bodies to myelin figures is consistent with a content of polar lipid which becomes hydrated to varying degrees and often ultimately dispersed or consumed. The results of extractions of lipid from developmental stages in Saprolegnia ferax show that the dense bodies could be largely phosphatidyl choline, which is itself a constituent of cell membranes (Rogers \& Perkins, I968). Polar lipid systems vary in structure according to the degree of hydration and may be greatly modified by the introduction of macromolecules of additional species (Stoeckenius, I962; Lucy \& Glauert, 1964). The lamellar intervals observed were greater than twice the molecular length of phosphatidyl choline and it is therefore unlikely that the bands consisted of layers of this substance alone. If present in them it was likely to have been combined with other materials, and probably hydrated.

Our finding that phosphatidyl choline may be present at higher concentrations in 
Saprolegnia ferax during sporogenesis than in the preceding vegetative phase is complementary to the recent report by Katsura (1970) that the amounts of phosphatidyl choline and phosphatidyl ethanolamine in zoospores of Phytophthora capsici diminish during the swimming period. Katsura has suggested that these phospholipids may serve as an energy reserve utilized during swimming and germination. The loss during the return to vegetative growth may be compared with the reduction in quantity of dense bodies in S. ferax at successive steps in the whole cycle from sporogenesis to germination.

These correlations between the structural changes and the chemical analyses lead to the general hypothesis that in some or in all oomycetes specific phospholipids (phosphatidyl choline and phosphatidyl ethanolamine) are utilized in morphogenesis and metabolism and are associated particularly with the functional activities of the dense-body vesicles, and that at least under some circumstances these lipids accumulate in vesicles immediately before induction of the reproductive cycle.

Vesicles with contents similar to the dense bodies have been found in other groups of organisms, for example in the yellow phaneroplasmodium of a Myxomycete (McManus, 1965) and in Euglena species and some other flagellates (Leedale, 1967). In the last two the vesicles contained lamellae or myelin figures and have been designated phospholipid vesicles, a descriptive term which, if the chemical nature of the contents can be substantiated, seems appropriate also for the dense-body vesicles in oomycetes. As centres of membrane development they resemble the gamma vesicles in Blastocladiella emersonii (Truesdell \& Cantino, I969). They are sufficiently characteristic in structure and behaviour to be considered organelles of status comparable to that of lysosomes and the various categories of microbodies found in higher plants and animals, but specifically distinct in function and not necessarily homologous with any one of these; evidence of enzyme content of the vesicles is required before a closer comparison can be made.

The investigation of the fine structure has not revealed in any of these examples the source and mode of origin of the dense-body vesicles nor any factors which may determine the preferred direction in which coalescence and expansion occur, although in cleavage these are fixed in relation to positions taken up beforehand by the nuclei.

We thank Miss M. Martin for technical assistance in the ultramicrotomy and the photography. One of us (A.D.G.) acknowledges with gratitude the assistance and encouragement give by Professor I. Manton, F.R.S., when the micrographs in Plate 2 were made in the Department of Botany, the University of Leeds, in 1953. Support has been given by the Science Research Council through a Research Contract with one of us (J.L.G.) and a Research Studentship (I. B.H.).

\section{REFERENCES}

BRACKER, C. E. (I966). Ultrastructural aspects of sporangiospore formation in Gilbertella persicaria. Colston Papers 18, 39-58.

BRACKER, C. E. (1968). The ultrastructure and development of sporangia in Gilbertella persicaria. Mycologia 6o, 1016-1067.

Chambers, T. C. \& Willoughby, L. G. (1964). The fine structure of Rhizophlyctis rosea, a soil Phycomycete. Journal of the Royal Microscopical Society 83, 355-364.

Chapman, J. A. \& Vujičić, R. (I965). The fine structure of sporangia of Phytophthora erythroseptica. Journal of General Microbiology 4r, 275-282. 
FREERE, R. H. \& WeIBEL, E. R. (1967). Stereologic techniques in microscopy. Journal of the Royal Microscopical Society 87, 25-34.

GAY, J. L. \& GREENWOOD, A. D. (1966). Structural aspects of zoospore production in Saprolegnia ferax with particular reference to the cell and vacuolar membranes. Colston Papers 18, 95-108.

HARTOG, M. M. (1888). Recent researches on the Saprolegniaceae: a critical abstract of Rothert's results. Annals of Botany 2, $20 \mathrm{I}-2 \mathrm{I} 6$.

Heath, I. B., GaY, J. L. \& Greenwood, A. D. (I971). Cell wall formation in Saprolegniales: Cytoplasmic vesicles underlying developing walls. Journal of General Microbiology 65, 225-232.

Heath, I. B. \& Greenwood, A. D. (1968). Electron microscopic observations of dividing somatic nuclei in Saprolegnia. Journal of General Microbiology 53, 287-289.

HeAth, I. B. \& Greenwood, A. D. (I970). Centriole replication and nuclear division in Saprolegnia. Journal of General Microbiology 62, I 39-148.

Ho, H. H., ZaChaRiah, K. \& Hickman, C. J. (I968). The ultrastructure of zoospores of Phytophthora megasperma var. sojae. Canadian Journal of Botany 46, 37-41.

HoHL, H. R. \& НАмамото, S. T. (1967). Ultrastructural changes during zoospore formation in Phytophthora parasitica. American Journal of Botany 54, I I 3 I-I 139.

KATsURA, K. (1970). Swimming behaviour of Phytophthora capsici zoospores. In Morphological and Related Biochemical Events in Host-Parasite Interaction, pp. 20-29. East-West Center, Honolulu, Hawaii. The United States-Japan Cooperative Science Program.

KING, J. E., Colhoun, J. \& ButLeR, R. D. (I968). Changes in the ultrastructure of sporangia of Phytophthora infestans associated with indirect germination and ageing. Transactions of the British Mycological Society 51, 269-281.

LeeDale, G. F. (1967). Euglenoid Flagellates. Englewood Cliffs, New Jersey: Prentice-Hall.

LESSIE, P. E. \& LovETT, J. S. (1968). Ultrastructural changes during sporangium formation and zoosporangium differentiation in Blastocladiella emersonii. American Journal of Botany 55, 220-236.

LUCY, J. A. \& GLAUERT, A. M. (I964). Structure and assembly of macromolecular lipid complexes composed of globular micelles. Journal of Molecular Biology 8, 727-748.

MaNGold, H. K. (1965). Aliphatic lipids. In Thin-layer Chromatography, pp. 137-186. Edited by E. Stahl. Berlin and Heidelberg: Springer-Verlag.

McManus, M. A. (1965). Ultrastructure of Myxomycete plasmodia of various types. American Journal of Botany 52, 15-25.

MOORE, R. T. (1964). Zoospore formation in the phycomycete Allomyces. Journal of Cell Biology 23, IOga.

MOORE, R. T. \& HowARD, K. L. (1968). Ultrastructure of oosporogeny in Saprolegnia terrestris. Journal of Cell Biology 39, 94 a.

ReICHLE, R. E. (1969). Fine structure of Phytophthora parasitica zoospores. Mycologia 6x, 30-51.

REYNoLDS, S. (1963). The use of lead citrate at high $\mathrm{pH}$ as an electron-opaque stain in electron microscopy. Journal of Cell Biology r7, 208-21 I.

Rogers, H. J. \& Perkins, H. R. (1968). Cell Walls and Membranes. London: E. and F. N. Spon.

RotherT, L. (1888). Die Entwicklung der Sporangien bei den Saprolegnieen. Cohn's Beiträge zur Biologie der Pflanzen 5, 291.

Shatla, M. N., YANG, C. Y. \& Mrtchell, J. E. (1966). Cytological and fine structure studies of Aphanomyces eutiches. Phytopathology 56, 923-928.

Stoeckenius, W. (1962). Structure of the plasma membrane. Circulation 26, 1066-1069.

TonTz, J. C. (1969). An Ultrastructural Study of Morphogenesis in Achlya ambisexualis Raper E87 and Achlya imperfecta Coker. Ph.D. thesis, University of Texas, Austin.

TRUesdell, L. C. \& CANTINo, E. C. (1969). The gamma particle: membrane source for germination in the zoospore of Blastocladiella emersonii. Journal of Cell Biology 43, 148a.

\section{EXPLANATION OF PLATES}

\section{Plate I}

Developing sporangia of Saprolegnia ferax.

Fig. I. Section showing part of a zoospore lying close to the containing sporangium wall $(w)$. A single plasmalemma is present. $\mathrm{KMnO}_{4} \cdot \mathrm{em} 3873 . \times 70,000$. 
Journal of General Microbiology, Vol. 65, No. 2

Plate I
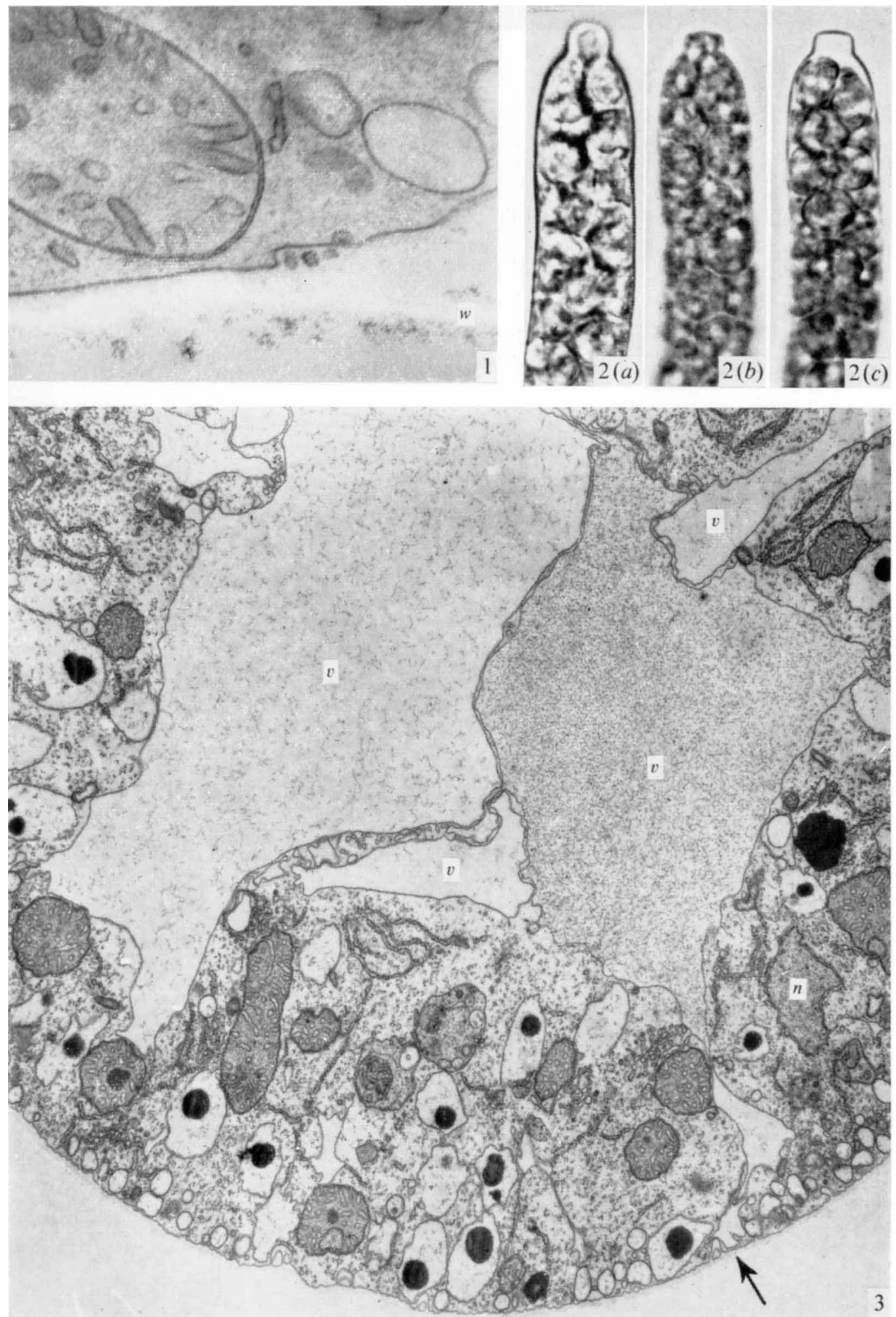
Journal of General Microbiology, Vol. 65, No. 2

Plate 2
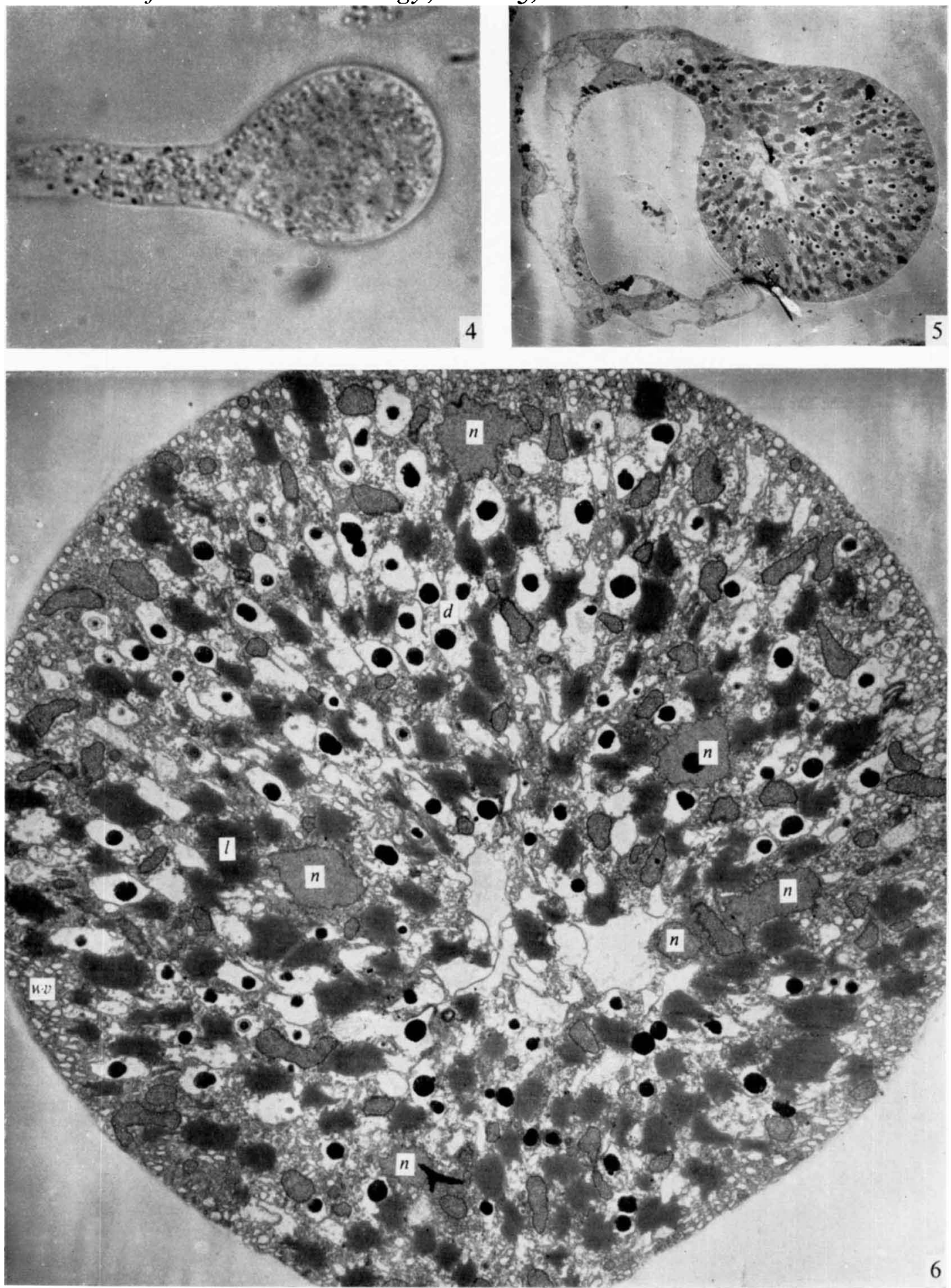

J. L. GAY, A. D. GREENWOOD AND I. B. HEATH 
Journal of General Microbiology, Vol. 65, No. 2

Plate 3
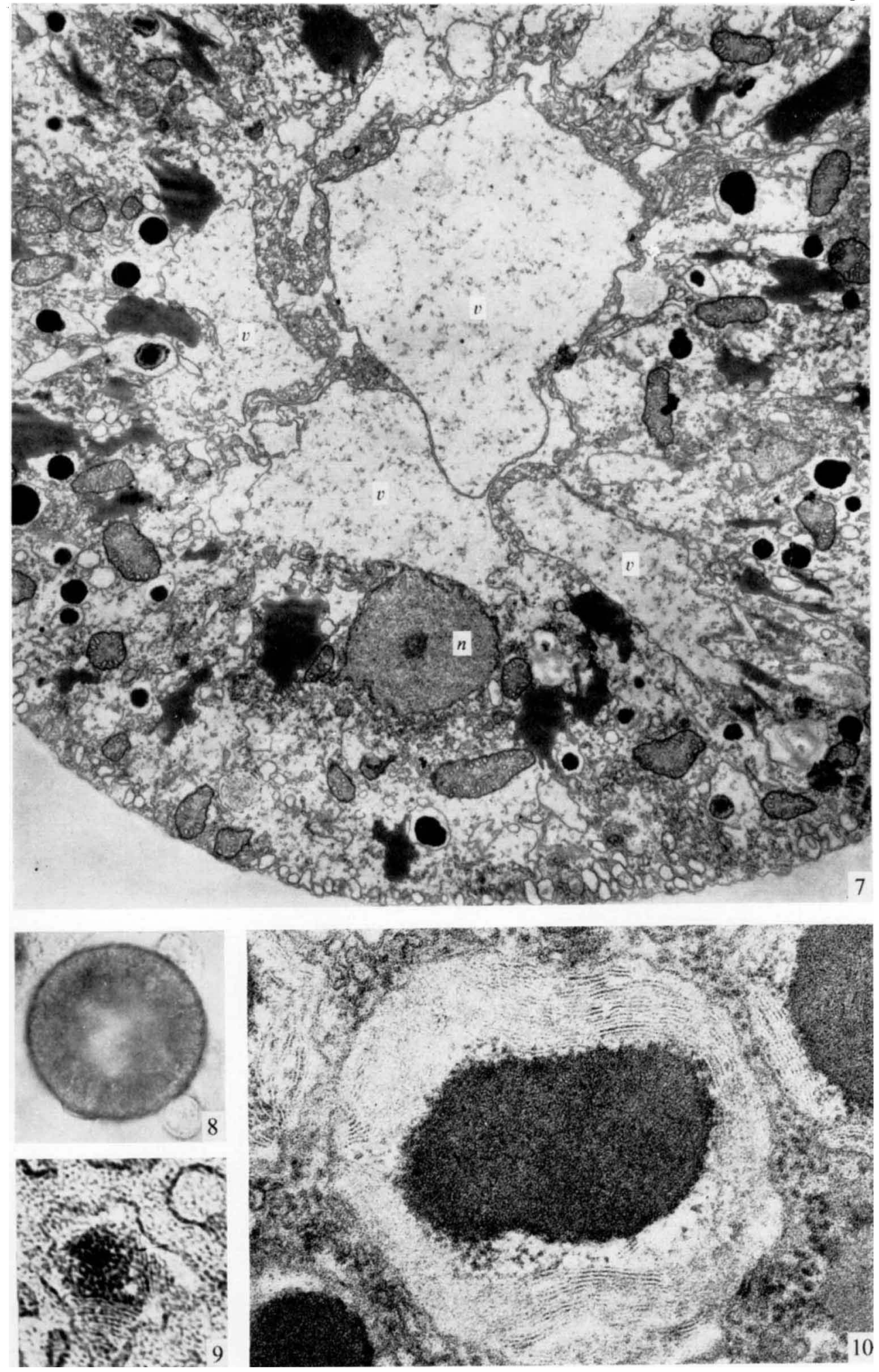

J. L. GAY, A. D. GREENWOOD AND I. B. HEATH 


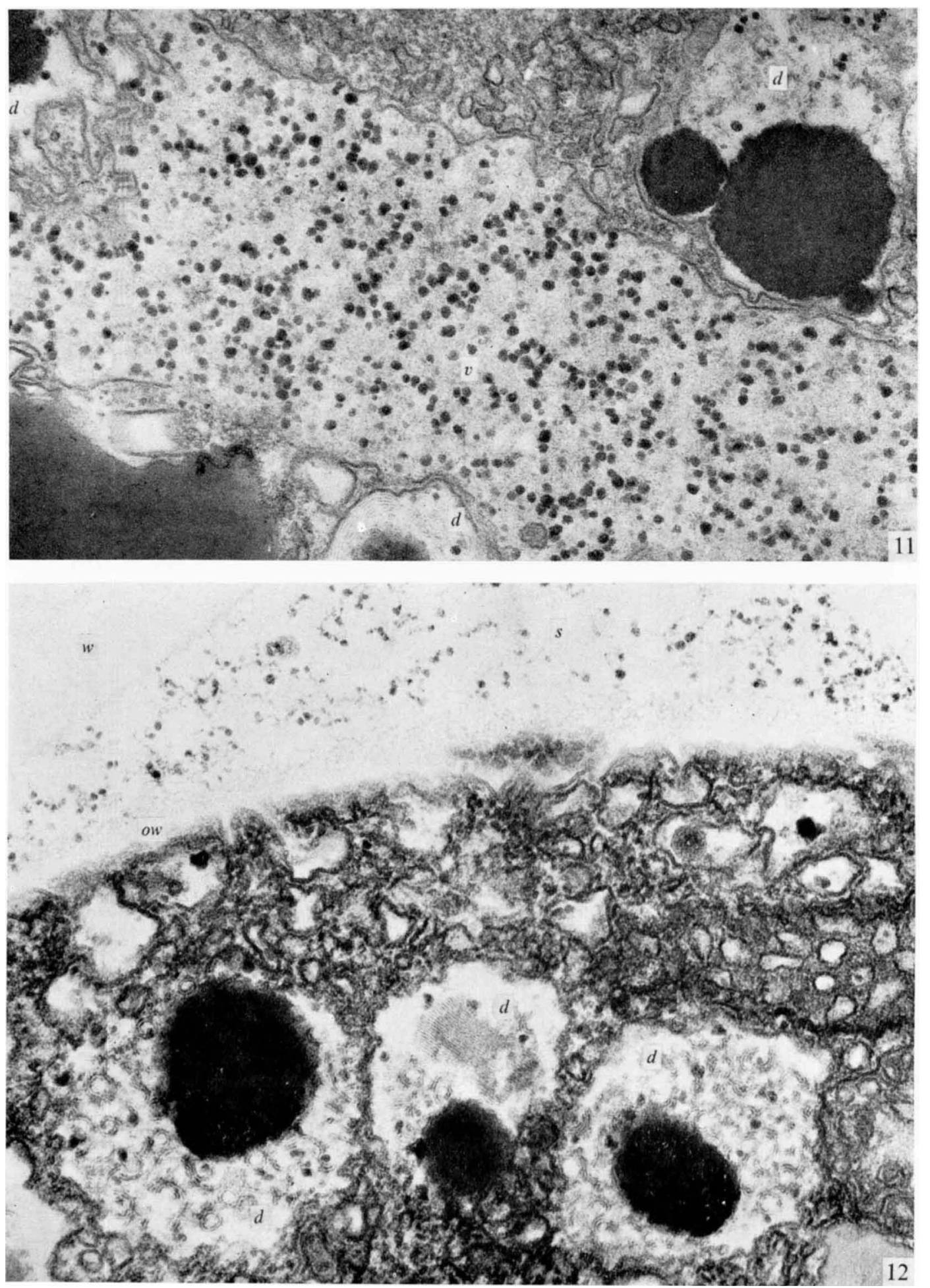

J. L. GAY, A. D. GREENWOOD AND I. B. HEATH 
Journal of General Microbiology, Vol. 65, No. 2
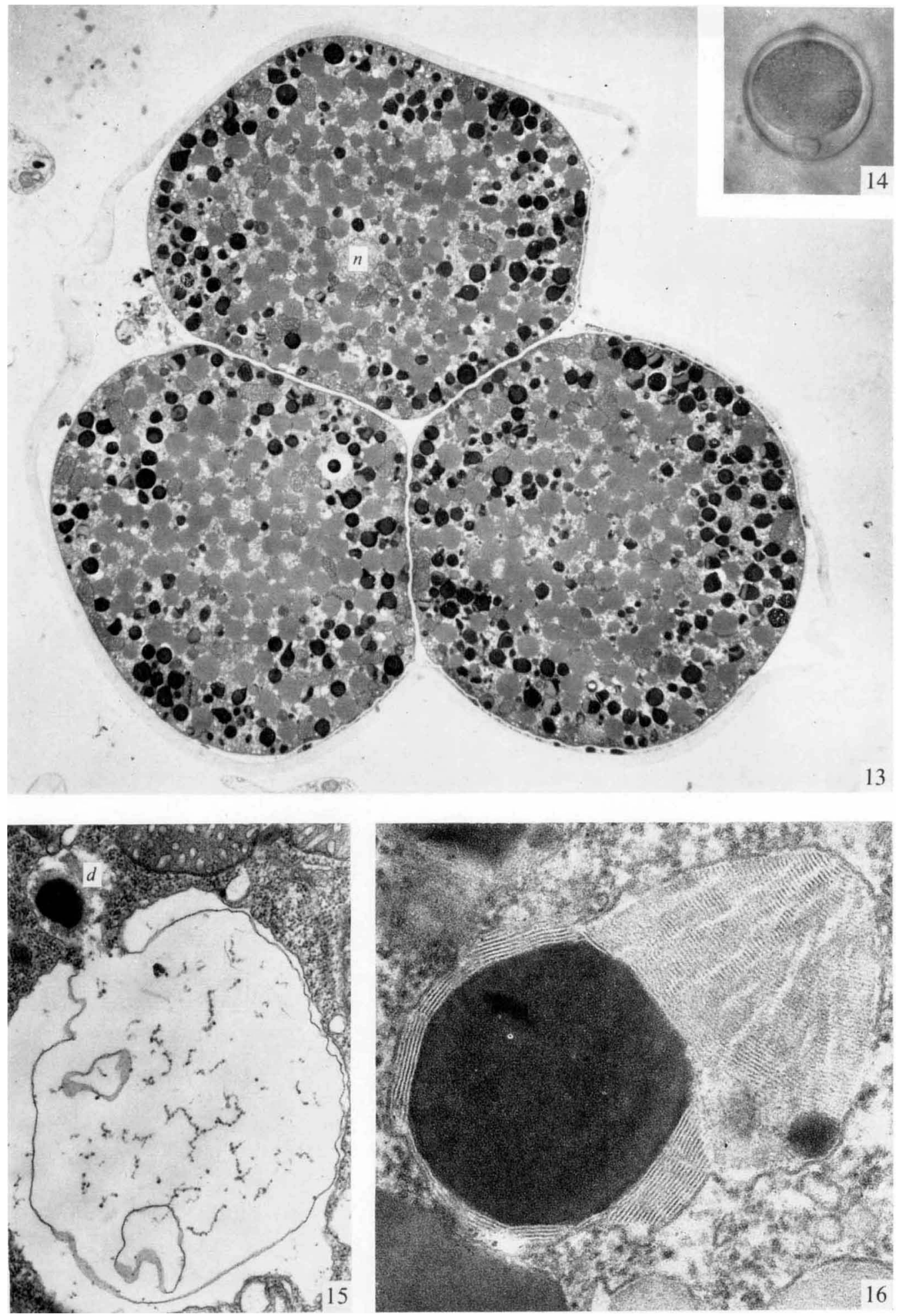

J. L. GAY, A. D. GREENWOOD AND I. B. HEATH 


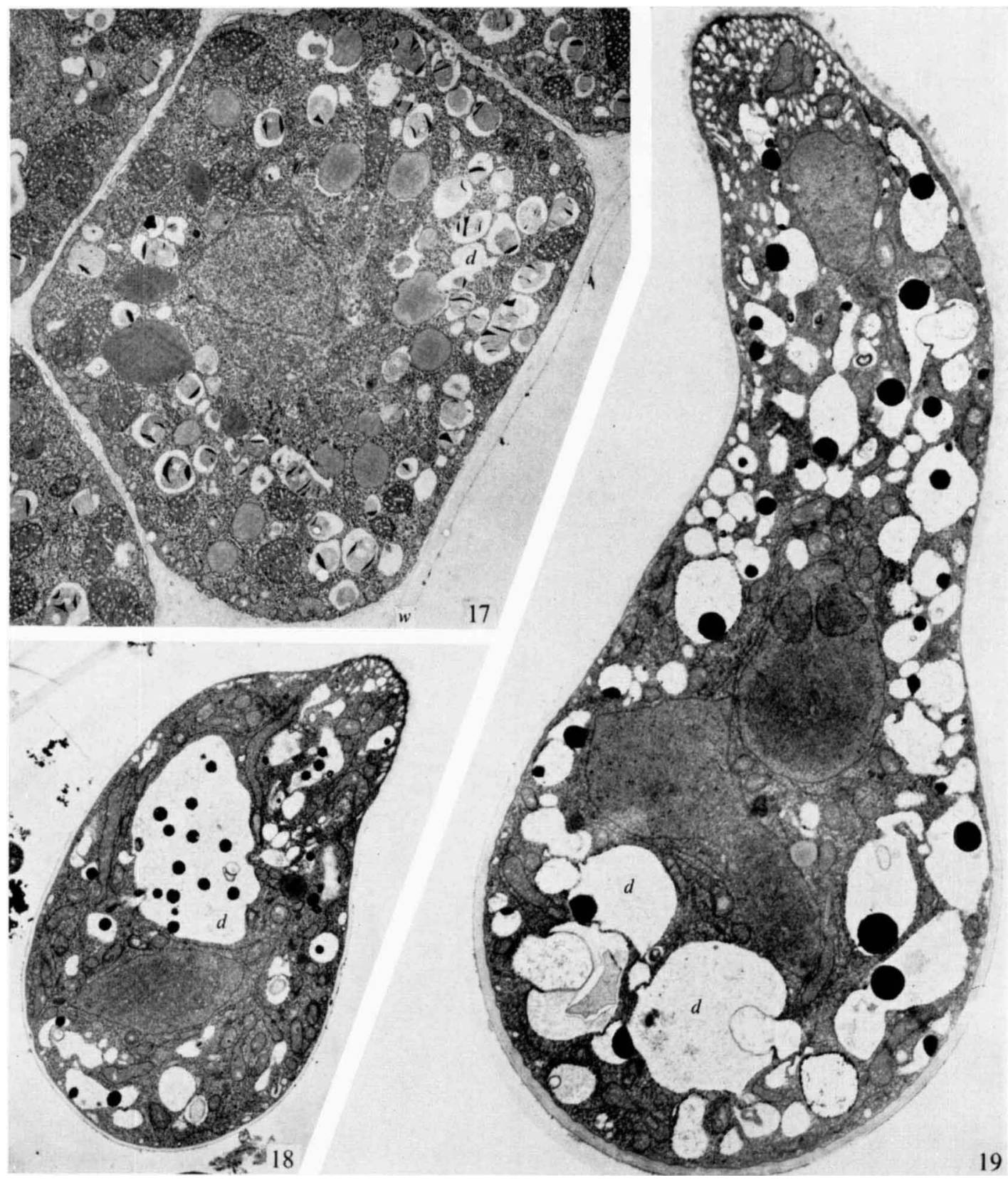


Fig. 2. Successive light micrographs of the apical region: $(b)$ and $(c)$ were obtained I and Io min. respectively after $(a)$. The apical papilla, fully developed in $(a)$, has collapsed in $(b)$ and the spores are less distinct. In $(c)$ the zoospores are mature and have contracted from the sporangium wall which remains in its shrunken condition. $\times 680$.

Fig. 3. Transverse section showing large vesicles (v), contiguous in the central region and with extensions which almost contact the plasmalemma (arrow). A nucleus $(n)$ is shown in one lobe of the cytoplasm. $\mathrm{OsO}_{4}$. em I466I. $\times \mathrm{I}_{3}, 200$.

\section{Plate 2}

Oogonia of Saprolegnia furcata immediately before the formation of a cross-wall.

Fig. 4. Light micrograph of living material. o 678. $\times$ I 210.

Fig. 5. Median section showing antheridium hypha arising from oogonium stalk and in contact with the oogonium body. $\mathrm{OsO}_{4} . \mathrm{em} 10606 . \times 1150$.

Fig. 6. Median section showing many dense-body vesicles $(d)$ and wall vesicles $(w v)$, neutral lipid $(l)$ and six nuclei $(n) . \mathrm{OsO}_{4}$.em $10442 . \times 4900$.

\section{Plate 3}

Fig. 7 and 8. Oogonia of Saprolegnia furcata immediately before cleavage of the protoplast.

Fig. 7. Median section, showing large vesicles $(v)$ contiguous in the central region and with extensions towards the periphery of the cell. A nucleus $(n)$ is shown in a lobe of the cytoplasm. OsO $\mathrm{O}_{4}$. em I0426. $\times 8000$.

Fig. 8. Light micrograph of living oogonium showing granular cytoplasm at the periphery and a uniform, less-dense central region. The oogonium stalk and two antheridia are shown. $0673 . \times 680$.

Fig. 9. Part of a young sporangium of Saprolegnia ferax. A dense-body vesicle with lamellate contents. $\mathrm{KMnO}_{4}$. em $10500(a) . \times 69,000$.

Fig. 10. Part of a young oogonium of Saprolegnia furcata. Dense-body vesicles containing concentric lamellae surrounding amorphous central regions. $\mathrm{OsO}_{4}$. em $12818 . \times 74,200$.

\section{Plate 4}

Parts of oogonia of Saprolegnia furcata.

Fig. 11. Before cleavage. Fig. 12. After cleavage of the protoplast, showing thin wall of oosphere (ow) and thicker oogonium wall $(w)$. Note identity of granules in dense-body vesicles $(d)$ in fig. I 1 and 12 with those in a central vesicle $(v)$ in fig. I I and the oogonium space $(s)$ in fig. I2. Fig. I $1: \mathrm{OsO}_{4}$. em 88Io, $\times 62,000$. Fig. I2: $\mathrm{OsO}_{4}$. em 10608. $\times 62,000$.

\section{Plate 5}

Fig. 13. Oogonium of Saprolegnia furcata. Section showing three oospheres with thin walls lying free within the space enclosed by the thicker oogonium wall. Dense bodies and neutral lipid are conspicuous. A nucleus $(n)$ is shown in one oosphere. $\mathrm{OsO}_{4} . \mathrm{em} 10470 . \times 3600$.

Fig. 14. Light micrograph of living oogonium with a single oosphere. A fertilization tube traverses the oogonium space. $0676 . \times 650$.

Fig. I 5. Part of a zoospore of Saprolegnia ferax. A dense-body vesicle (d) has an extension into the neighbouring vacuole. Glut/OsO $\mathrm{O}_{4}$.em $12004 . \times 20,200$.

Fig. I6. Part of an oogonium of Saprolegnia furcata. Lamellae surround an amorphous region in a dense-body vesicle. Glut/OsO $\mathrm{O}_{4}$.em $8572 . \times 74,000$.

\section{Plate 6}

Fig. 17. Part of a sporangium of Dictyuchus sterile, showing encysted spores and sporangium wall $(w)$. The dense-body vesicles $(d)$ have contents characteristically different from those in Saprolegnia species. Glut $/ \mathrm{OsO}_{4}$. em $12163 . \times 7100$.

Fig. 18 and 19. Germinating zoospores of Saprolegnia ferax. Wall vesicles occupy the apical regions and the dense-body vesicles $(d)$ are expanded. In fig. 18 one vesicle contains several dense bodies. Fig. 18: Glut/OsO 4 .em 8956. $\times 4700$. Fig. 19: Glut/OsO ${ }_{4} \cdot \mathrm{em} 8945 . \times 6200$. 